\title{
Impact of Hurricanes on Peach and Pecan Orchards in the Southeastern United States
}

\author{
Gregory L. Reighard ${ }^{1}$ \\ Department of Horticulture, Clemson University, Clemson, SC 29634-0375 \\ Michael L. Parker \\ Department of Horticultural Science, North Carolina State University, Raleigh, NC 27695-7609 \\ Gerard W. Krewer \\ Department of Horticulture, University of Georgia, Tifton, GA 31793-1209 \\ Thomas G. Beckman and Bruce W. Wood \\ U.S. Department of Agriculture, Agricultural Research Service, Southeastern Fruit and Nut Tree Research \\ Laboratory, Byron, GA 31008 \\ John Ed Smith \\ Pierce County Extension Service, University of Georgia, Blackshear, GA 31516 \\ Johnny Whiddon \\ Brooks County Extension Service, University of Georgia, Quitman, GA 31643
}

Hurricane and tropical storm damage to the tree fruit and nut industry in the Carolinas and Georgia over the past decade has been significant. Generally, hurricanes are thought to be more of a problem to coastal areas where few tree fruit are grown. However, recent hurricanes with landfalls on the southeastern coast of the United States have reached production areas up to $320-400 \mathrm{~km}$ inland, with wind speeds from $128-176 \mathrm{~km} / \mathrm{h}$, often preceded by torrential rainfall (i.e., 20-30 cm). These hurricane-associated winds and rains have had a large negative impact on crops such as peaches [Prunus persica (L.) Batsch] and pecans [Carya illinoinensis (F.A. Wagenheim) K. Koch]. The primary problems with hurricanes and tropical storms are the combined effects of excessive rain, followed by high winds. Winds also come from both the front and back of a hurricane, beginning in the southeastern United States with northeastern winds from the storm's counterclockwise circulation, and ending with southwestern winds. These winds break limbs and remove leaves and fruit from fruit and nut trees. In addition, this change of wind direction by $180^{\circ}$ (i.e., twisting effect) seriously damages the root system of trees, and may uproot the whole tree. Flooding further stresses the affected trees. In addition, in coastal areas tidal surges and salt spray can also damage trees. Recent reports have described past hurricane damage, pest outbreaks, pre- and poststorm cultural practices, and recommendations for future hurricanes for subtropical tree fruit crops (Crane et al., 1994) and southeastern forests (Barry et al., 1993). This paper will describe hurricane and tropical storm damage to peach and pecan trees based upon both shortand long-term observations in the field, and will review cultural practices that have helped amend past orchard damage and may potentially minimize damage from future storms.

\section{HURRICANE EFFECTS ON NORTH CAROLINA PEACH AND PECAN TREES}

\section{Peach}

The effects of hurricanes on peach production in North Carolina have been relatively mild based upon visual estimates of damage to peach trees. When hurricanes hit, primarily in September, the peach crop has already been harvested. Therefore, the weight on the aboveground portion of the tree is greatly reduced, and the canopy is also

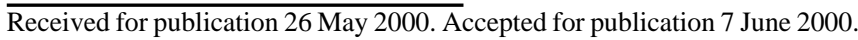
The cost of publishing this paper was defrayed in part by the payment of page charges. Under postal regulations, this paper therefore must be hereby marked advertisement solely to indicate this fact.

${ }^{1}$ To whom correspondence should be addressed. Email address: grghrd@clemson.edu thinning out as the growing season progresses. Peach trees are normally dormant-pruned to 2-3 $\mathrm{m}$ in height, thus reducing the canopy area that can be affected by high winds. Because of the reduced canopy and fruit crop, wind damage to the above-ground structure is minimal and uprooting is rare. The primary problem is the damage that occurs to the root system. The heavy rain and alternating high winds cause trunk movement in the wet soil and create an open area around the collar of the tree. The amount of root damage and injury from this tree movement is unknown. Since peach trees are relatively shallowrooted, many of the fine feeder roots near the soil surface may be destroyed, thereby reducing the potential for water and nutrient uptake. The effects of this root destruction on crop potential of peach and pecan during the following year have not been determined.

\section{Pecan}

The tree crop in North Carolina that suffers the most severe damage from hurricanes is pecan. Since the majority of the trees are not harvested until October, they are at great risk to hurricane damage because of their height (up to $30+\mathrm{m}$ ) and the full nut crop during hurricane season. At the very least, the nuts are blown off prematurely during minor hurricanes and tropical storms. When a crop load of 50$100 \mathrm{~kg}$ on a $15-30+\mathrm{m}$ tree is subjected to hurricane force winds, a significant stress is created on the tree structure and root system. In addition, the thick foliage of a tall pecan tree acts as a very large "sail" in capturing wind. With hurricane-force winds lasting 6-10 h, the result is shredded leaves at best, with defoliation being common. The defoliated trees do not produce or transport to the roots the carbohydrates that are necessary for normal cropping the following year. This can lead to an off-production year and cause alternate bearing.

Since pecan trees are shallow-rooted, rainfall of $13-23 \mathrm{~cm}$ in 6-12 $\mathrm{h}$ can often lead to tree upheaval. This has been a major problem in pecan orchards in North Carolina during a hurricane. Even if the trees are not completely uprooted, the damage to the root system is extensive and tree removal may be advisable. However, the most dramatic damage occurs to the aerial structures, when weak and brittle limbs are broken by hurricane-force winds. Moreover, pecan trees are frequently trained to a multi-leader form with many acute crotch angles. Hurricane-force winds may split the central or multi-leaders that are weakened by bark inclusions, resulting in damage extending well into the heartwood. This type of damage reduces tree vigor over time because of structural, fungal, and secondary insect damage, and the trees never recover to their full cropping potential. Younger trees (1015 years old) may be broken off $2-3 \mathrm{~m}$ above the soil surface. Trees in this age group may be salvaged by cutting off the broken top and growing a new canopy. However, if tree damage is extensive, replant- 
ing may be the most economical approach. Trees in which major limbs are damaged or broken during hurricanes lose significant cropping potential for up to 3-5 years. Despite extensive wind damage, the North Carolina pecan industry has expanded in the past decade. However, many of the new pecan and peach orchards being established are relatively small ( $2-5 \mathrm{ha})$.

\section{HURRICANE HUGO IMPACTS ON SOUTH CAROLINA PEACH AND PECAN ORCHARDS}

On 21 Sept. 1989, Hurricane Hugo, a category 4 hurricane with winds of up to $224 \mathrm{~km} / \mathrm{h}$, made landfall near Charleston, S.C., and moved northwesterly through Charlotte, N.C. (National Oceanic and Atmospheric Administration, 2000). Hugo was one of the strongest storms to reach the South Carolina mainland in 35 years.

\section{Peach}

The eye of this hurricane passed through three peach-growing regions in South Carolina: the Coastal Plain, Sandhills, and Piedmont areas. Short-term effects from Hugo's 112 to $144 \mathrm{~km} / \mathrm{h}$ winds were immediate and destructive. Trees suffered defoliation, broken scaffolds, split trunks, trunk breakage, uprooting and tilting. Away from the coast, flooding was not extensive because of the direct track and speed of the hurricane. Long-term impacts, up to 10 years later, appeared to be less obvious, as few standing trees of bearing age died except in low or poorly drained areas.

Hugo's impact on peach orchards was similar in all three geographic regions of South Carolina. Orchards in the Coastal Plain suffered the most short- and long-term damage. Orchards not protected by adjacent forests had appreciable wind damage, and the soil was waterlogged in those orchards not planted on beds or without adequate drainage. Root and wood rots also appeared to be more of a long-term problem. Sandhill area orchards had various degrees of wind damage but few water-related problems. Piedmont area orchards had the most wind damage, probably because of a number of 'minitornadoes' embedded in the storm. Flooding was not a problem in these orchards.

Tree age was a major determinant of short-term tree damage from Hurricane Hugo in all three peach areas. Sustained winds of about 128 $\mathrm{km} / \mathrm{h}$ around the hurricane's eye affected second and third leaf trees most. These nonbearing trees had large canopies without a large or extensive root system and thus were vulnerable to being blown over or twisted by the $180^{\circ}$ change in wind direction as the hurricane passed over. Many of these trees ( $>50 \%$ in some cases) died because of trunk twisting above the root system even after being reset and staked. Most first-year trees were also leaning or blown over, but responded very well to staking, except for exceptionally vigorous trees that had damage similar to second- and third-year trees.

Fourth- through sixth-year trees exhibited a wide range of damage depending on orchard site and tree vigor. These trees had the densest canopies and the strongest structural wood (less wood rots, etc.) and thus intercepted the most wind. Orchards near forests generally were bent $>30-45^{\circ}$ from vertical. Unprotected trees had scaffold breakage, or in the case of very open or wet areas, were uprooted.

Repositioning leaning trees with heavy equipment and bolting split scaffolds back together gave mixed results. As many as $75 \%$ of the trees were saved in some orchards, while in others as many as $75 \%$ declined and died. Holes in the soil just below the graft union were the principal reason for success or failure in this age class and were associated with soil type and orchard location. Deep-rooted trees protected by nearby forests responded best to repositioning. Exposed orchard sites with restricted soil rooting depth due to high water tables or impermeable subsoils did not respond well. Leaning, but not uprooted, trees that were left alone and later retrained upright by pruning generally survived best, unless extensive twisting about the trunk axis had occurred.

Seventh-year and older trees that were healthy generally withstood the storm, although most of them were left leaning, depending on orchard location and site. Trees that were shallow-rooted, had incipient root or heart rots, and were located in low (i.e., wet) or exposed areas were more likely to be blown down or have broken scaffolds. Repositioning these trees appeared to have no noticeable positive effect, and in some cases did more damage by breaking undamaged roots.

\section{Pecan}

Hurricane Hugo also impacted the South Carolina pecan industry. As mentioned above, pecans are vulnerable to hurricane-force winds. Hurricane Hugo blew down many pecan trees and severely damaged many others. For the most part, growers did not try to right downed trees. Some even removed damaged orchards instead of pruning out the damage. Most of the 1989 crop and the leaves were blown off trees that were in the path of the hurricane. Old orchards were affected most, probably because of their large size (20-30+ $\mathrm{m}$ tall). The majority of these orchards were never replanted, since they were generally small orchards rented out to other growers.

\section{Recovery}

Long-term damage from Hurricane Hugo to the South Carolina peach industry has been minimal. Most trees continued to produce good fruit crops despite being tilted or partially uprooted. Orchards in low areas were not replanted, which was prudent. The use of raised beds in new orchards increased significantly in the Coastal Plain and Piedmont after Hugo. Ten years after Hugo, many impacted orchards on good sites have few dead trees. In addition, first-year orchards that were staked upright after Hugo show no effects of past wind damage. Orchard trees that were on marginal sites or whose trunks and scaffolds were bolted also had high survival, but scaffold breakage from fungal rots and overall tree decline were more prevalent. In contrast, the longterm impact of Hurricane Hugo on the pecan industry was a reduction in acreage in South Carolina in the areas affected by the high winds. Economic factors at that time did not encourage replanting of the damaged orchards.

\section{ALBERTO AND EL NIÑO EFFECTS ON PEACH PRODUCTION IN SOUTHERN AND CENTRAL GEORGIA}

Peach trees in southern Georgia are frequently planted on Tifton and similar soil series with a slope of $0 \%$ to $5 \%$. The top layer of these soils is commonly a well-drained, loamy sand, but the subsoil is frequently a sandy clay loam with low permeability. During normal rainfall conditions the roots grow into the subsoil, but then die from lack of oxygen, and the roots rot during periods of abnormally high rainfall. Weakened trees are also subject to attack by Ambrosia beetles that often finish the killing process.

During periods of abnormally high rainfall, such as Tropical Storm Alberto and allied storm events of Fall 1994, and the El Niño event of Winter and Spring 1997-98, a number of peach orchards were seriously injured by the saturated soil conditions. During Tropical Storm Alberto in July 1994, the early-season production areas in southcentral and southwestern Georgia received more than $25 \mathrm{~cm}$ of rain$10 \mathrm{~cm}$ more than the 15-cm average for July (Coastal Plains Experiment Station records, Tifton, Ga.). Some surrounding areas received even more. In Oct. 1994, these same areas were inundated with 25-36 $\mathrm{cm}$ of rain, which is much higher than the 6-cm October average. Furthermore, the aforementioned El Niño event dropped a total of 96 $\mathrm{cm}$ of rain during a 4-month period, which is nearly equal to the normal annual rainfall.

Problems from Alberto became evident in late Spring 1995 as fruit of early-season peach cultivars, such as 'Flordaking', began their final swell. Shoot elongation and fruit enlargement ceased on large numbers of trees that had appeared healthy during spring and early summer. Upon investigation, severe damage to the trunk was discovered several centimeters below the soil surface. This damage typically consisted of brown necrotic bark, under which was usually found a white rot of the internal woody tissues. While no positive laboratory identifications were made of the fungal organisms involved, the fruiting bodies that subsequently developed on a small number of trees appeared to be those of the genera Oxyporous and Ganoderma. Later observations by 
south Georgia growers suggested that trees that had these symptoms in 1995 should have been removed at that time. These trees died over the next 3 years despite efforts to save them through fruit removal and pruning practices.

Tree loss was often greatest in two areas of the orchards-on relatively flat hilltops where water drained off the hill slowly, and at the lower elevations along hillsides where perched water tables created temporary springs. Estimated peach tree loss from these two events in Brooks County, the largest peach-growing county in southern Georgia, was $30 \%$. Growers estimate that $20 \%$ to $100 \%$ of the surviving trees sustained residual damage, depending on orchard location. One commercial peach grower in Pierce County (southeastern Georgia) who had planted trees on raised beds missed most of the Alberto event, but experienced very high rainfall during the El Niño year. An estimated $5 \%$ of his trees died and another $20 \%$ suffered damage. The raised beds appeared to have limited tree loss. In Irwin County, Ga., following El Niño, a grower lost most of a 7-ha peach block that was planted without raised beds on a flat hilltop. The entire block was removed because the number of surviving trees was so small. The net effect of these tropical storms has been to create localized but massive damage to some peach orchards in southern Georgia.

In contrast, very few trees generally died in orchards in the main production area in central Georgia following these rainfall events, despite the fact that Tropical Storm Alberto dropped $25-50 \mathrm{~cm}$ of rain over an 86-h period (National Weather Service, 1994) in early July 1994. Peach orchards were inundated from 1-2 d to 1-2 weeks. Most trees flooded for $<4 \mathrm{~d}$ survived except for second- and third-leaf trees, the majority of which died. These nonbearing trees had large canopies in relation to their root mass and did not tolerate flooding conditions as well as did those in other age classes. First-year trees survived the flooding very well for reasons not yet understood, as did older trees. In one mature orchard that was flooded to a height of $\approx 1.5 \mathrm{~m}$ for some time, all the branches under water were killed, as was the orchard floor vegetation. However, the shoots remaining above the water line survived, continued growth and the trees survived. Tree losses in other age classes were usually in low areas in fields, but most trees flooded for 4 or more d exhibited severe leaf rolling symptoms before recovering. Long-term survival following this storm was generally good, with few problems associated with root rots and Ambrosia beetles. One extenuating circumstance that probably greatly reduced the impact of the flooding was that, for about a month after Alberto, the weather was unusually cool and cloudy, which reduced evaporative demand (i.e., water stress). Other important factors were the superior internal soil drainage of the Faceville fine sandy loams typically used for peach production in this part of the State, and the fact that this area was spared the heavy October rains experienced in southern Georgia. Overall, Tropical Storm Alberto alone did not have much impact on peach acreage in south or central Georgia during the 1990s, but, in combination with other high rainfall events, caused extensive tree loss and damage in south Georgia.

\section{SUMMARY}

Review of recent history (past 10 years) of the short- and long-term impacts of hurricanes and tropical storms on peach and pecan trees in the Southeast suggests that both water and wind are damaging factors in peaches, while wind is the major problem for pecans. Preventative measures for peaches for future storms include preplant bedding on flat areas, improving drainage using ditches and tile drains, prestorm shearing of overly vigorous young trees (if done before September), planting appropriate windbreak species, and maintaining healthy, deep-rooted peach trees through recommended cultural practices. Practices to reduce hurricane damage in pecans rely largely on improving drainage, but implementing whole-tree shearing practices to reduce canopy volume and planting architecturally desirable cultivars may someday become a cost-effective alternative cultural system.

\section{Literature Cited}

Barry, P.J., C. Doggett, R.L. Anderson, and K.M. Swain. 1993. How to evaluate and manage storm-damaged forest areas. U.S. Dept. of Agr. For. Serv. Southern Region Mgt. Bul. R8-MB 63.

Crane, J., C. Balerdi, R. Campbell, C. Campbell, and S. Goldweber. 1994. Managing fruit orchards to minimize hurricane damage. HortTechnology 4:21-27.

National Oceanic and Atmospheric Administration. 2000. Hurricane Hugo (1998) overview. Website www.csc.noaa.gov/. 